\title{
Elevation promotes long-term survival of Pinus elliottii var. densa, a foundation species of the endangered pine rockland ecosystem in the Florida Keys
}

\author{
Grant L. Harley ${ }^{1, *}$, Justin T. Maxwell ${ }^{2}$, George T. Raber ${ }^{1}$ \\ ${ }^{1}$ Department of Geography and Geology, The University of Southern Mississippi, 118 College Drive, Box \#5051, Hattiesburg, \\ MS 39406, USA \\ ${ }^{2}$ Department of Geography, Indiana University, 701 E. Kirkwood Avenue, 120 Student Building, Bloomington, IN 47405, USA
}

\begin{abstract}
The pine rockland community in southern Florida, which supports numerous stateand federally listed flora and fauna species, is considered endangered. Without its foundation species, Pinus elliottii var. densa, habitat and species diversity are lost to tropical hardwood hammock. Here, we investigate the landscape factors that contribute to the long-term persistence of pine rocklands on the 2 islands that contain the largest remaining habitat in the Florida Keys: Big Pine Key and No Name Key. Plot-level biophysical data and island-scale remotely sensed vegetation data were collected from pine rockland savannas and examined with multi-dimensional analysis. On both islands, vegetation plots located at higher elevations contain the greatest basal area and the oldest and largest-diameter trees. In contrast, the lowest-elevation plots contain more standing dead trees and downed logs. Change-detection analysis of the normalized difference vegetation index between 2001 and 2011 supports the notion that habitat areas at lower elevations experience more vegetation change compared to those at higher elevations during the time period $(\mathrm{p}<0.05)$. Trees rooted at higher elevations frequently exceeded $200 \mathrm{yr}$ in age, which is uncommon in this highly disturbed sub-tropical region. Although elevation range on the 2 islands was only ca. 0 to $3 \mathrm{~m}$, these results demonstrate that higher elevations can act as a refuge for the saltintolerant $P$. elliottii var. densa during storm surge events, which promotes long-term development of old-growth savanna structure and aids the long-term persistence of pine rocklands in the Florida Keys.
\end{abstract}

KEY WORDS: Microtopography · Disturbance ecology · Forest structure • Tropical cyclone • Storm surge $\cdot$ Pine savanna

\section{INTRODUCTION}

Pine rockland is an endangered community currently restricted to small areas of southern peninsular Florida and islands in the lower Florida Keys. In the lower Keys, rockland savannas are characterized by a rich assemblage of herbaceous flora with many narrowly endemic taxa scattered along the understory and a single-species canopy of Pinus elliottii var.

*Corresponding author: grant.harley@usm.edu densa (Sah et al. 2004). P. elliottii var. densa is the foundation species of pine rocklands because it contributes extensively as a primary producer and plays an important role in structuring the community. A key characteristic of $P$. elliottii var. densa within the community is that it provides fuel (e.g. needles) which frequently facilitates the spread of fire across the landscape. In the absence of fire, savanna-like pine rocklands succeed to closed-canopy tropical

() The authors 2015. Open Access under Creative Commons by Attribution Licence. Use, distribution and reproduction are unrestricted. Authors and original publication must be credited. 
hammock, and with this succession many endangered flora and fauna species are also lost. Fire and available fresh groundwater via a freshwater lens are the 2 primary determinants of whether an upland site in the Keys will be dominated by pines or broadleaf species (Ross et al. 1992, 1994).

Disturbances, those initiated naturally or by humans, impart change in many ecosystems by impacting community dynamics or the composition, structure, and successional trajectories of forest systems through time. Topography is one of the most important predictors of vegetation composition within a given region (Danz et al. 2011), especially within bottomland or coastal ecosystems prone to periodic flooding. The frequency and intensity of disturbance regimes can have varying affects on communities with regard to fine-scale elevation variance and localscale topographic conditions (Foster 1988, Hylander 2005, Åström et al. 2007). Certain topographic features, such as boulders, can act as a refugium to promote increased survival rates of species impacted by floods (Matthaei et al. 2000), fire (Kiss \& Magnin 2003), and clear-cut logging (Schmalholz \& Hylander 2011). Previous studies have already demonstrated the adverse effects of sea level rise and tropical cyclone (TC) disturbance on individual species as well as vegetation communities on the low-relief islands of the Florida Keys. Ross et al. $(1994,2009)$ found sea level rise-induced vegetation shifts from a mesophytic pine rockland to a halophytic community on Sugarloaf Key, Florida. Maschinski et al. (2011) noted that increased groundwater salinity levels caused a rapid decline in the population of federally endangered Pilosocereus robinii (Key tree cactus). A recent report by the US Fish and Wildlife Service (USFWS) highlighted the failure to identify any Anaea troglodyta floridalis (Florida leafwing butterfly) individuals following devastating impacts from Hurricane Wilma in 2005 (USFWS 2009).

Less understood, however, is how disturbance interacts with fine-scale elevation change to impact the structure of ecosystems at decadal to centennial time scales. In the Florida Keys, Ross et al. (1994) found that topographic position was related to widespread patterns of pine mortality resulting from sea level rise and subsequent salinization of the groundwater and soil. Such studies facilitate better understandings of the capacity for a community to recover from a disturbance, such as a TC. In this study, we test the potential linkage between fine-scale elevation variance and vegetation structure with regard to impacts from TCs over the past several centuries.
The primary large-scale meteorological disturbance agent in coastal ecosystems of the southeastern USA is TCs (Platt et al. 2000). The physical impacts associated with TC landfalls include wind damage, coastal flooding and erosion, and storm surge-induced salt deposition. Although the role of TCs as a natural disturbance agent is well documented in the southeastern USA (e.g. Pimm et al. 1994, Platt et al. 2000, Batista \& Platt 2003, Lugo 2008), the effects of sea level rise on coastal plant communities is becoming a primary concern for agencies charged with restoring and conserving coastal environments (Hopkinson et al. 2008, Ross et al. 2009, Maschinski et al. 2011). In the Florida Keys, both fire and elevation might dictate the ability of plants to recover following wind damage and storm surge. In 1965, storm surge associated with Hurricane Betsy measured $2.74 \mathrm{~m}$ in North Key Largo (Needham \& Keim 2012). In 1995, 30 yr following Hurricane Betsy, elevation did not explain the abundance of $P$. elliottii var. densa or of Chamaesyce lineata, a rare endemic herbaceous plant, but explained significant variations in abundance of the endemic C. deltoidea (S. Saha et al. 2011). In 2005, Hurricane Wilma caused a $6.43 \mathrm{~m}$ surge on Vaca Key (Needham \& Keim 2012), which neighbors Big Pine Key (BPK). Three years after Hurricane Wilma, in 2008, elevation and abundance were strongly and positively correlated for all 3 aforementioned species. Further, tree mortality rate from the Hurricane Wilma storm surge was highest in the larger sizes classes of $P$. elliottii var. densa, the foundation species of pine rocklands (Sah et al. 2010). The effects of storm surge from Hurricane Wilma were exacerbated by topography and infrastructure (e.g. road berms, spoil) that caused water to collect and remain at the surface for an extended time, likely contributing to widespread mortality of salt-intolerant species.

Since $1851 \mathrm{CE}, 53 \mathrm{TCs}$ (categories 1 to 5) and 71 tropical storms tracked within $200 \mathrm{~km}$ of the Florida Keys (centered at $24.6909^{\circ} \mathrm{N}, 81.3699^{\circ} \mathrm{W}$; hurricane database HURDAT, www.nhc.noaa.gov; Fig. 1). The largest island in the lower Florida Keys is BPK, which currently contains the most contiguous area of pine rockland habitat. Because BPK is situated geographically along the Florida Straits between the Gulf of Mexico and the Atlantic Ocean, the island has a long history of repeated storm surge inundation. Since 1880, at least 3 storm surge events on BPK that exceeded $4 \mathrm{~m}$ were recorded and included in the storm surge database SURGEDAT (http://surge.srcc.lsu. edu/data.html; Needham \& Keim 2012). Given that large areas of pine rockland habitat on BPK were completely inundated with storm surge on multiple 


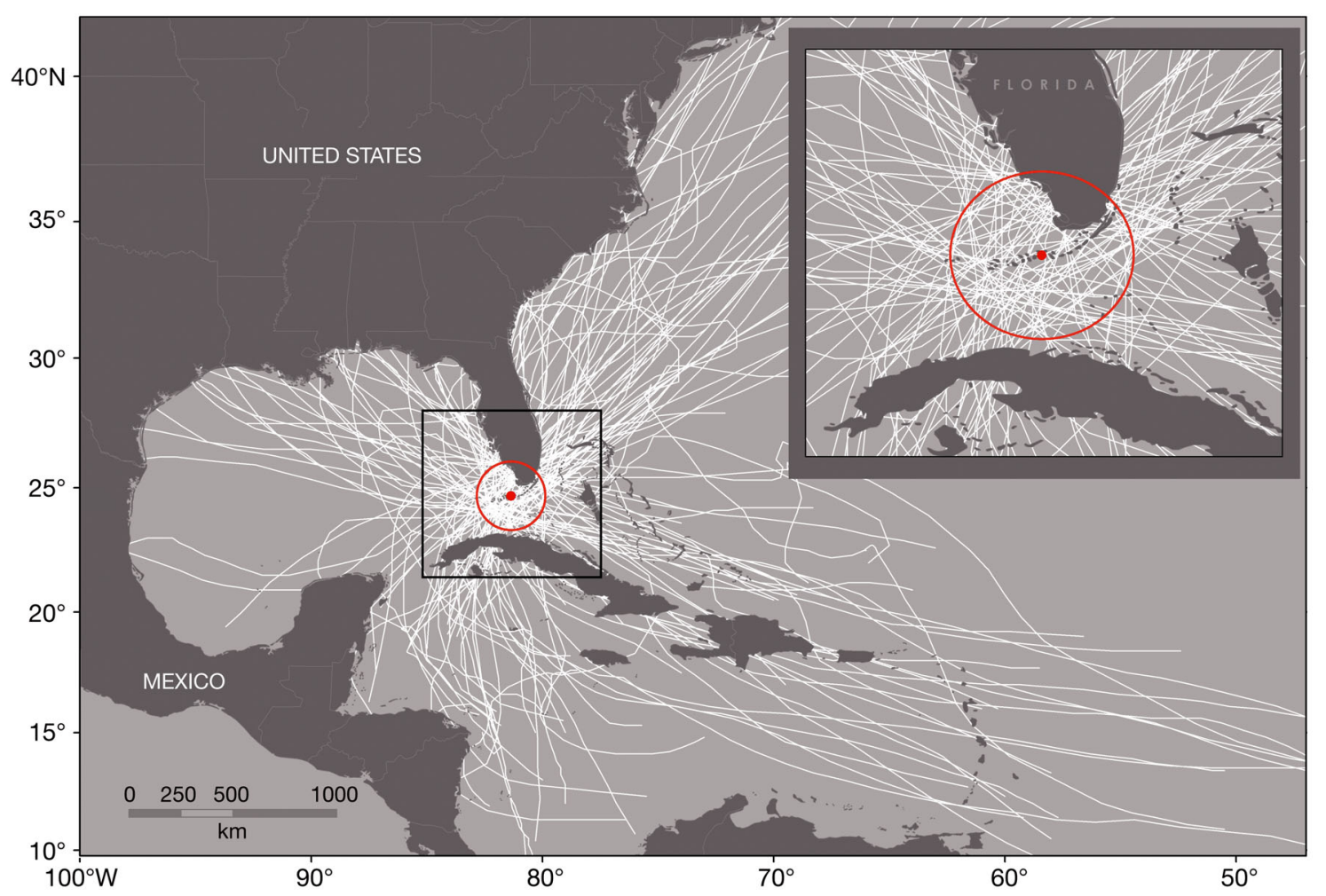

Fig. 1. Historical tropical cyclones that tracked within $200 \mathrm{~km}$ (red circle) of Big Pine Key (red dot) and No Name Key, Florida, during the period 1850-2014. Calculation of $200 \mathrm{~km}$ buffer zone centered on Big Pine Key at 24.6909 N, 81.3699 W. Hurricane tracks from the hurricane database HURDAT, accessed at www.nhc.noaa.gov

occasions in the recent past, one would expect to find a vegetation structure that showed evidence of a primary succession event across the entire island (i.e. even-aged pine savannas). Yet, the structure of the pine rockland savannas in the Florida Keys resembles that of old coastal plain P. palustris savannas in the southeastern USA (Platt et al. 1988, Platt \& Rathbun 1993, Palik \& Pederson 1996) - a mosaic of evenaged habitat patches within an uneven-aged, complex savanna, with some $P$. elliottii var. densa individuals exceeding $225 \mathrm{yr}$ in age (Harley et al. 2013).

Long-term perspectives of coastal ecosystem resiliency would aid restoration and conservation efforts aimed at preserving the endangered pine rockland community and associated species. Restoring and conserving pine rocklands is challenging, given the frequent fire regime that must be maintained (Bergh \& Wisby 1996, Harley et al. 2013), widespread land use change and habitat fragmentation, the influence of repeated TCs, and impending sea level rise caused by climate change (Ross et al. 2009). At the forefront of conservation efforts is the Florida Keys region, where rockland habitat exists at a maximum of ca. $3 \mathrm{~m}$ above sea level. Within the restoration ecology paradigm, several central issues exist that influence restoration or conservation options for a community. In the face of disturbance, Maschinski et al. (2011) outlined the issues of population demography, dispersal mechanisms, suitable habitat, and policy, which all influence the options for restoration/conservation faced by natural resource managers. Spatial and temporal vegetation data could be used to identify core conservation areas with respect to environmental controls, particularly within low-relief ecosystems in coastal locations.

In this study, we use data from primary and secondary sources to test the hypothesis that island locations with higher elevation promote the long-term persistence of pine rockland habitat in the Florida Keys. To test this hypothesis, we use ground-based biophysical vegetation structure data and explicit ages of canopy-dominant $P$. elliottii var. densa individuals at study sites on 2 adjacent islands: BPK and No Name Key (NNK). Further, we incorporate a 10 yr change-detection analysis of the normalized difference vegetation index (NDVI) regarding elevation zones at BPK and NNK. The distance of plot location from the coast could have an effect on vegetation 
structure and tree survival from TCinduced disturbance. Thus, we investigated the impact that distance from the coast might have on habitat structure and in promoting increased survival rates of $P$. elliottii var. densa following TC events. Similar to plot elevation, we included a distance from coast term as a dependent variable.

\section{MATERIALS AND METHODS}

\section{Study area}

The islands of BPK $\left(24.70^{\circ} \mathrm{N}\right.$, $\left.81.37^{\circ} \mathrm{W}\right)$ and $\mathrm{NNK}\left(24.69^{\circ} \mathrm{N}, 81.32^{\circ} \mathrm{W}\right)$ contain the largest areas of pine rockland habitat in the Florida Keys. Pine rocklands provide an important habitat for several federally and state-listed endangered fauna such as the Key deer Odocoileus virginianus clavium, the lower Keys marsh rabbit Sylvilagus palustris hefneri, Kirtland's warbler Dendroica kirtlandii, and the Florida leafwing butterfly Anaea troglodyta floridalis (Snyder et al. 1990). Predominant palm and shrub species include saw palmetto Serenoa repens, silver palm Coccothrinax argentata, brittle thatch palm Thrinax morrisii, wax myrtle Myrica cerifera, myrsine Rapanea punctata, and poisonwood Metopium toxiferum, and common herbaceous species include bluestems Andropogen spp., lopsided Indiangrass Sorghastrum secundum, pineland croton Croton linearis, and partridge pea Chamaecrista fasciculata (Ross et al. 1992).

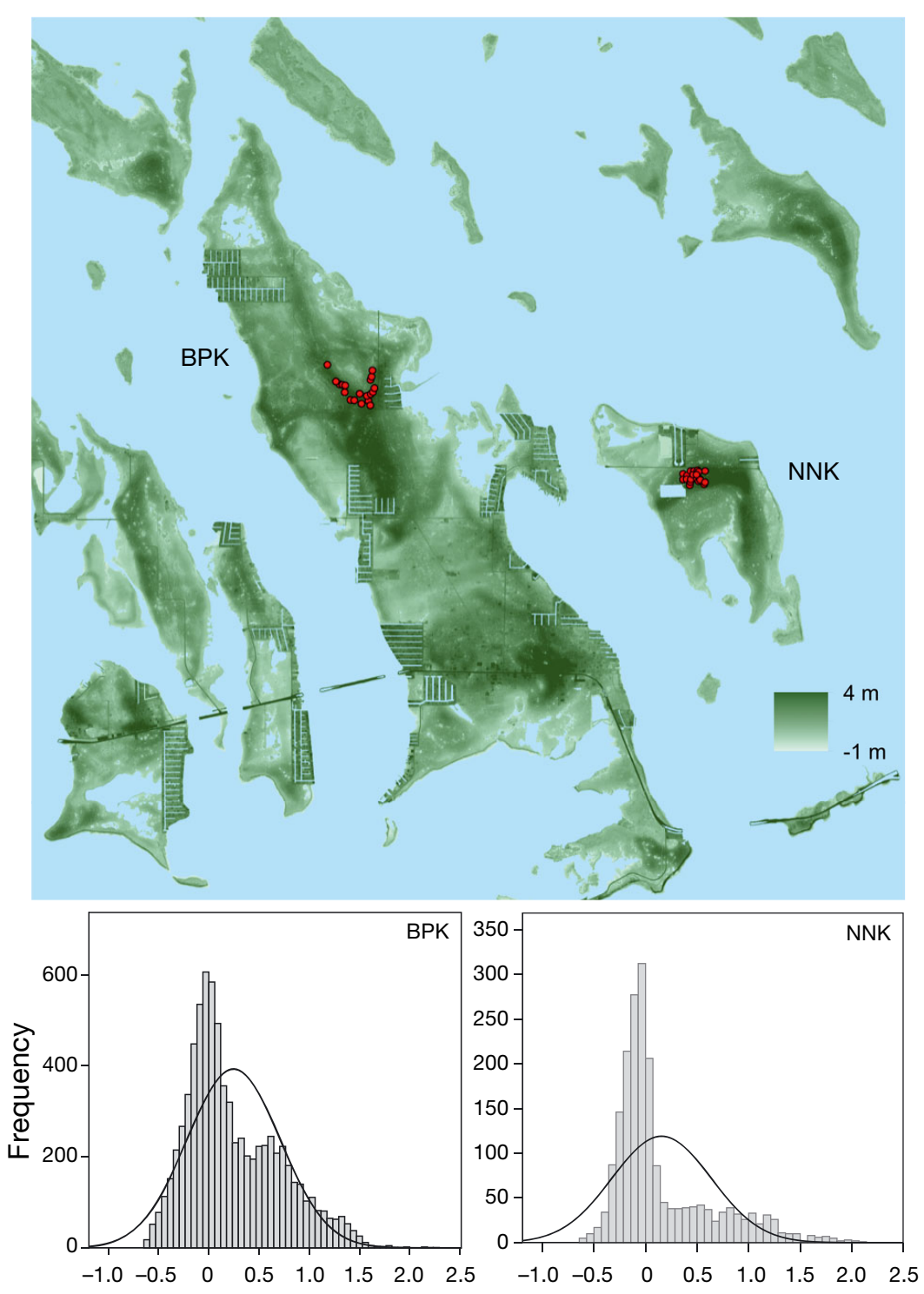

Fig. 2. LiDAR digital elevation model, elevation frequency distributions, and vegetation plot locations (red dots) for the islands at Big Pine Key (BPK) and No Name Key (NNK), Florida Keys, USA. The dashed line on the map is US Route 1. Note the different scales on the $y$-axes (frequency) in the bottom panel

\section{Vegetation dynamics}

We randomly established 20 circular plots (area $=$ $0.04 \mathrm{ha}$ ) each at the BPK and NNK sites to document the biophysical vegetation structure (Fig. 2). On both BPK and NNK, we selected 75 ha tracts of pine rockland habitat in which to install vegetation plots. Plot center locations were taken via GPS for subsequent assignment of plot elevation. In each plot, we recorded diameter at breast height $\left(\mathrm{dbh}_{i}\right.$ ca. $1.4 \mathrm{~m}$ above the surface) for all stems $\geq 5 \mathrm{~cm}$ dbh to quantify stand size structure. We collected increment cores from all living Pinus elliottii var. densa individuals at a height of $30 \mathrm{~cm}$ above the ground surface to evaluate establishment date and tree age. Increment cores were taken with a $5.15 \mathrm{~mm}$ diameter Haglöf increment borer, with 2 radii extracted from each tree. In each plot, we also recorded the frequency and dbh for all snags and logs to quantify the abundance and size of coarse woody debris.

Tree cores were prepared using standard techniques (Stokes \& Smiley 1968), and tree age was as- 
signed based on the innermost growth ring for cores that contained the pith. We applied an age correction to cores that missed the pith based on the curvature of the innermost rings with pith estimators that represented different growth rates (Applequist 1958). For each plot, we also tallied $P$. elliottii var. densa abundance and calculated quadratic mean diameter (QMD) from dbh measurements. We included QMD because this metric assigns greater weight to larger trees and, thus, could provide a more accurate depiction of oldgrowth structure (Curtis \& Marshall 2000).

\section{Elevation and spatial analysis}

Remotely sensed LiDAR-derived elevation data, flown in 2007, were obtained from the Nature Conservancy (www.nature.org), and each plot center and old-growth individuals were assigned an elevation based on GPS location. The horizontal error of the LiDAR data was $2.5 \mathrm{~m}$. Thus, if 2 randomly established plots were within the $2.5 \mathrm{~m}$ associated error, another plot center point was selected at random. We used Pearson correlation analysis to assess the relationship between independent variables (elevation and distance to coast) and mean values of dependent variables collected at plot level (age, number of snags and logs, dbh of snags and logs, basal area, QMD, and stem abundance). Based on initial correlations between dependent and independent variables, we used multivariate analysis to identify the main sources of variance in the datasets. Principal component analysis (PCA) and associated biplot graphical representation were used to assess the structural homogeneity with relation to elevation and distance to coast within the 40 plots at BPK and NNK. PCA also helped reduce problems associated with multicollinearity between dependent variables. For example, tree age and size are strongly correlated. On the biplot representations for BPK and NNK, the vegetation structure parameters were positioned relative to axes for principal components 1 and $2\left(\mathrm{PC}_{1}\right.$ and $\left.\mathrm{PC}_{2}\right)$ and represented by vectors. Structural vectors were plotted with the site vegetation plots. Finally, plots were separated into low, middle, and high elevation groups, and mean parameters were compared using 1-way ANOVA and Tukey-Kramer post hoc tests to better understand the influence of elevation on P. elliottii var. densa and pine rockland structure. Because plots were randomly established irrespective of elevation, the plot-assigned elevation range at each site varied. Thus, plots were placed into 1 of 3 groups defined by elevation range at BPK and NNK.

\section{Maximum tree age}

Failure to capture the oldest trees at each site was possible given that plots were established randomly. Thus, we used a targeted sampling design to select the oldest individuals based on visual characteristics (cf. Pederson 2010) that did not fall within a plot. Tree cores were extracted following aforementioned methods and crossdated visually and statistically. The exact location of each tree was acquired using a GPS and compared to the elevation dataset.

\section{Remote sensing}

Established remote sensing (RS) techniques were used to investigate the vegetation changes within BPK and NNK during the period 2001 to 2011 in elevation zones. We were particularly interested in observing if differences in vegetation over this time period were influenced by the small degree of elevation change that exists within the study area. Like many elements of the environment, vegetation has certain reflective characteristics that can be observed in RS data. Healthy vegetation absorbs much of the incident energy for use in photosynthesis, particularly those portions of the spectrum humans detect as blue and red, making plants appear green. Additionally, healthy plants reflect much of the energy in the near-infrared (NIR) portion of the spectrum to avoid overheating. Thus, the ratio of reflected NIR energy to red energy in healthy plants is high. Unhealthy or sparse vegetation will exhibit a similar pattern but with varying degrees of strength that correlate to the presence of healthy vegetation within a given area. A vegetation index is an indicator derived from RS data that describes the relative density and health of vegetation for each picture element (pixel) in a satellite image. One of the primary vegetation indexes used for this purpose is the NDVI:

$$
\mathrm{NDVI}=(\mathrm{NIR}-\mathrm{Red}) /(\mathrm{NIR}+\mathrm{Red})
$$

Previous studies have taken advantage of indices such as these to map vegetation variables such as health, intensity, biomass, and fraction of absorbed photosynthetically active radiation using RS data because these indices are found to correlate well with these observable vegetation characteristics. Since we performed this study post hoc, we were not able to collect in situ vegetation data; rather, we relied on previous studies indicating that NDVI is highly correlated with many vegetation parameters. Thus, we use the change in NDVI values to investi- 
gate the relative amount of vegetation change occurring at various elevation zones over the time period.

We acquired 2 images of the study area from the Global Land Cover Facility (www.landcover.org). The first image was acquired on 13 November 2001 by the Enhanced Thematic Mapper Plus sensor onboard Landsat 7 . The second was acquired ca. $10 \mathrm{yr}$ later, on 10 November 2011, but because of issues with the scan line corrector that occurred in 2003 onboard Landsat 7, the image we selected was actually acquired by the older Thematic Mapper sensor onboard Landsat 5 (Fig. 3). For the portions of the spectrum of concern in this study (red and NIR), the spectral range of both sensors is nearly identical. The images were orthorectified and projected into the Universal Transverse Mercator coordinate system (Zone 17 North). Images were then normalized radiometrically using empirical line calibration with dark and bright locations, with the older image serving as reference, and NDVI values were calculated for the entire dataset. To provide further correction between the 2 images, we then minimum-maximum stretched the NDVI values in each dataset to a range between 0 and 1 . We then identified the absolute difference between the NDVI values for the 2 yr (2011 and 2001). The result was a dataset with numbers representing the magnitude of vegetation change for each pixel in the image.

To reduce error in the dataset (i.e. lawns, urban landscapes), we created a mask of areas to exclude from our study. Data from the 2011 National Land Cover Dataset, which were also derived from the 2011 Landsat image used in this study, were acquired; as a result, spatial resolution was identical
$(30 \times 30 \mathrm{~m})$, and all areas labeled as a developed category were excluded. Additionally, we removed other small areas that, based on observation, were also affected by changes that were anthropomorphic in nature. Finally, to further account for minor variability between the 2 images, we masked out all changes that were less than $2 \mathrm{SD}$ from the mean, thus leaving only larger changes for consideration.

To summarize the amount of observed vegetation change at various elevation zones on BPK and NNK, the dataset was projected to match the NDVI difference data and then binned into 3 elevation groups based on elevation distribution on each island (Fig. 2). Descriptive statistics were calculated, including the mean absolute change in NDVI between the 2 time periods for each of the elevation zones, and an ANOVA was performed to test if the differences in NDVI were significantly different between elevation zones.

\section{RESULTS}

\section{Vegetation structure}

The elevation range at the BPK and NNK sites based on plot-level data was 0.55 to $1.26 \mathrm{~m}$ and 0.43 to $1.31 \mathrm{~m}$, respectively. Distance of plots to the coast ranged from 500 to $968 \mathrm{~m}$ at BPK and from 480 to $685 \mathrm{~m}$ at NNK (Table 1). Pearson correlation analyses revealed no significant relationships between distance of plot locations to the coast and plot-level vegetation data collected at both sites ( $p>0.01$; Table 2$)$. At BPK and NNK, however, a significant relationship was found between mean plot elevation and mean
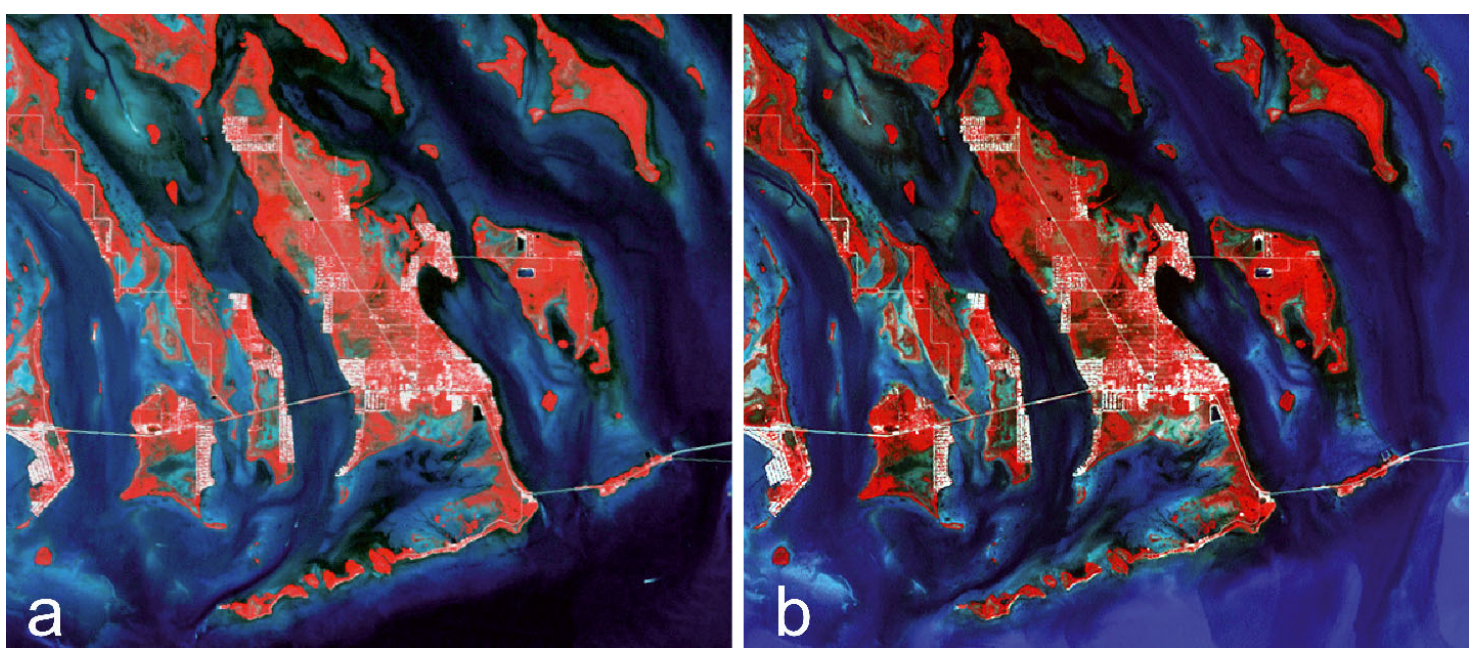

Fig. 3. False color representations of Landsat images acquired for Big Pine Key and No Name Key in (a) 2001 and (b) 2011 . Nearinfrared response is shown as red in the images (spectral bands 4 [red], 3 [green], and 2 [blue]); thin white line: US Route 1 
Table 1. Vegetation plot parameters for the Big Pine Key (BPK) and No Name Key (NNK) sites, Florida Keys, USA. Each site contained 20 randomly established plots from which biophysical data were acquired. QMD: quadratic mean diameter; BA: basal area; DD: dead and downed trees; dbh: diameter at breast height

\begin{tabular}{|c|c|c|c|c|c|c|c|c|c|}
\hline Site & Plot & $\begin{array}{l}\text { Age } \\
(\mathrm{yr})\end{array}$ & $\begin{array}{l}\text { QMD } \\
(\mathrm{cm})\end{array}$ & $\begin{array}{c}\text { BA } \\
\left(\mathrm{m}^{2} \mathrm{ha}^{-1}\right)\end{array}$ & $\begin{array}{l}\mathrm{DD} \\
\text { (n) }\end{array}$ & $\begin{array}{c}\mathrm{DD} \\
(\mathrm{dbh}, \mathrm{cm})\end{array}$ & $\begin{array}{l}\text { Abundance } \\
\text { (n) }\end{array}$ & $\begin{array}{c}\text { Elevation } \\
\text { (m.a.s.l) }\end{array}$ & $\begin{array}{c}\text { Distance } \\
\text { to coast (m) }\end{array}$ \\
\hline \multirow[t]{20}{*}{ BPK } & 1 & 33.1 & 11.3 & 0.11 & 5 & 13 & 11 & 1.02 & 500.8 \\
\hline & 2 & 111.3 & 22.3 & 0.24 & 9 & 5.9 & 3 & 1.47 & 521.9 \\
\hline & 3 & 77.2 & 19.3 & 0.17 & 8 & 11.9 & 6 & 1.32 & 622.1 \\
\hline & 4 & 62.5 & 18.6 & 0.16 & 5 & 12.9 & 6 & 1.37 & 703.1 \\
\hline & 5 & 74 & 20.5 & 0.23 & 7 & 12.9 & 7 & 1.18 & 768.1 \\
\hline & 6 & 72.8 & 17.4 & 0.09 & 15 & 12.9 & 4 & 1.07 & 541.5 \\
\hline & 7 & 58.5 & 13.2 & 0.16 & 14 & 7 & 12 & 0.74 & 515.5 \\
\hline & 8 & 80.8 & 17.8 & 0.11 & 10 & 8.6 & 10 & 0.81 & 451.6 \\
\hline & 9 & 59.2 & 15.3 & 0.16 & 17 & 9.1 & 14 & 0.84 & 451.2 \\
\hline & 10 & 27 & 12.4 & 0.07 & 21 & 9.4 & 6 & 0.64 & 536.5 \\
\hline & 11 & 72.6 & 15.6 & 0.21 & 9 & 8.8 & 9 & 0.92 & 529.2 \\
\hline & 12 & 40.6 & 11.8 & 0.06 & 13 & 13.5 & 8 & 0.71 & 548.4 \\
\hline & 13 & 56.6 & 15 & 0.15 & 11 & 7.3 & 9 & 1.02 & 669 \\
\hline & 14 & 84.4 & 16.6 & 0.19 & 20 & 10 & 9 & 1.17 & 905.2 \\
\hline & 15 & 50.4 & 12.4 & 0.13 & 12 & 7.2 & 11 & 0.91 & 843.4 \\
\hline & 16 & 53.5 & 15 & 0.1 & 3 & 11.2 & 6 & 0.92 & 796.7 \\
\hline & 17 & 60.8 & 17.1 & 0.11 & 9 & 9.5 & 5 & 1.21 & 888.7 \\
\hline & 18 & 67.5 & 15.9 & 0.21 & 0 & 0 & 8 & 1.32 & 968 \\
\hline & 19 & 78.9 & 19.7 & 0.25 & 6 & 17.7 & 7 & 1.43 & 903.3 \\
\hline & 20 & 70.9 & 16.8 & 0.15 & 3 & 11.3 & 7 & 1.1 & 933.3 \\
\hline \multirow[t]{20}{*}{ NNK } & 1 & 56.8 & 16.1 & 0.16 & 18 & 18.8 & 8 & 0.74 & 579.2 \\
\hline & 2 & 79 & 23.2 & 0.12 & 7 & 14.9 & 2 & 1.09 & 569.7 \\
\hline & 3 & 45.9 & 15.2 & 0.18 & 19 & 18.1 & 14 & 0.49 & 615.2 \\
\hline & 4 & 56 & 17.5 & 0.12 & 21 & 12.9 & 5 & 0.77 & 673 \\
\hline & 5 & 40.3 & 16.4 & 0.08 & 15 & 18.4 & 12 & 0.82 & 604 \\
\hline & 6 & 72.3 & 20.6 & 0.35 & 12 & 20 & 7 & 0.91 & 520.9 \\
\hline & 7 & 60.4 & 19.2 & 0.37 & 11 & 17 & 13 & 1.03 & 507.8 \\
\hline & 8 & 67.2 & 20.9 & 0.34 & 3 & 15.5 & 10 & 1.15 & 555.5 \\
\hline & 9 & 73.9 & 26.8 & 0.26 & 8 & 14.8 & 8 & 1.22 & 655.9 \\
\hline & 10 & 83 & 21.6 & 0.3 & 7 & 25 & 4 & 1.32 & 635.8 \\
\hline & 11 & 53.5 & 19.9 & 0.25 & 4 & 28.6 & 4 & 1.12 & 684.9 \\
\hline & 12 & 55.6 & 20.8 & 0.27 & 4 & 24.4 & 8 & 1.15 & 638.6 \\
\hline & 13 & 81.4 & 25.4 & 0.39 & 3 & 18.3 & 7 & 1.53 & 626.4 \\
\hline & 14 & 63 & 20.7 & 0.2 & 4 & 24.9 & 6 & 1.35 & 650 \\
\hline & 15 & 65.6 & 23 & 0.2 & 2 & 34 & 5 & 1.3 & 671.1 \\
\hline & 16 & 51.1 & 20.4 & 0.29 & 2 & 21.8 & 9 & 1.16 & 633.7 \\
\hline & 17 & 48.3 & 15.6 & 0.14 & 5 & 21.9 & 16 & 0.66 & 616.8 \\
\hline & 18 & 41.1 & 19 & 0.19 & 14 & 24.6 & 7 & 0.55 & 541.6 \\
\hline & 19 & 92 & 28.6 & 0.32 & 3 & 26.2 & 5 & 1.5 & 479.9 \\
\hline & 20 & 66.5 & 19.7 & 0.25 & 10 & 17 & 6 & 1.17 & 531.5 \\
\hline
\end{tabular}

age, number of snags and logs, basal area, QMD, and abundance ( $\mathrm{p}<0.05$; Table 2$)$.

Vegetation plots at BPK and NNK (Table 2) located at higher elevations contained the greatest basal area and a lower density of trees that were older and larger in diameter (Fig. 4). In contrast, plots located at lower elevations contained a higher abundance of trees that were smaller and younger as well as more standing dead trees and downed logs. PCA identified $1 \mathrm{PC}$ axis at each site with an eigenvalue greater than 1.0, although $\mathrm{PC}_{2}$ eigenvalues were close to 1. At $\mathrm{BPK}, \mathrm{PC}_{1}$ and $\mathrm{PC}_{2}$ explained 56 and $20 \%$ of the total variance, respectively (Table 3). At NNK, 60 and $20 \%$ of the total variance was explained by $\mathrm{PC}_{1}$ and $\mathrm{PC}_{2}$, respectively. At BPK and NNK, we found statistically significant correlations between $\mathrm{PC}_{1}$ and tree age $(r=0.90 ; r=0.89)$, dead and downed trees $(r=$ $0.43 ; \mathrm{r}=0.70), \mathrm{QMD}(\mathrm{r}=0.95 ; \mathrm{r}=0.93)$, basal area $(\mathrm{r}=$ $0.78 ; \mathrm{r}=0.67)$, and abundance $(\mathrm{r}=0.54 ; \mathrm{r}=0.60)(\mathrm{p}<$ 0.05). The distribution of plots at both sites and grouping patterns about structural vectors support the hypothesis that plots located at different elevations contain different forest structure (Fig. 5). On $\mathrm{BPK}$, the ANOVA tests demonstrated that vegetation 
Table 2. Correlation matrices showing relationships between independent and dependent variables (units given in rows only) for vegetation plots at the Big Pine Key (BPK) and No Name Key (NNK) study sites, Florida Keys, USA. QMD: quadratic mean diameter; BA: basal area; DD: dead and downed trees; coast: distance to coast; dbh: diameter at breast height. ${ }^{*} \mathrm{p}<0.05 ;{ }^{* *} \mathrm{p}<0.01$

\begin{tabular}{|c|c|c|c|c|c|c|c|c|}
\hline & Age & QMD & $\mathrm{BA}$ & DD (n) & DD (dbh) & Abundance & Elevation & Coast \\
\hline \multicolumn{9}{|l|}{ BPK } \\
\hline Age (mean, yr) & - & $0.87^{* *}$ & $0.72^{* *}$ & -0.16 & -0.11 & -0.35 & $0.65^{* *}$ & 0.13 \\
\hline $\mathrm{QMD}(\mathrm{cm})$ & $0.87^{* *}$ & - & $0.67^{* *}$ & -0.29 & 0.12 & $-0.56^{*}$ & $0.77^{* *}$ & 0.19 \\
\hline $\mathrm{BA}\left(\mathrm{m}^{2} \mathrm{ha}^{-1}\right)$ & $0.72^{* *}$ & $0.67^{* *}$ & - & -0.31 & -0.13 & -0.06 & $0.69^{* *}$ & 0.31 \\
\hline $\mathrm{DD}(\mathrm{n})$ & -0.16 & -0.29 & -0.31 & - & -0.01 & 0.23 & $-0.53^{*}$ & -0.04 \\
\hline $\mathrm{DD}(\mathrm{dbh}, \mathrm{cm})$ & -0.11 & 0.12 & -0.13 & -0.01 & - & -0.18 & 0.07 & -0.03 \\
\hline Abundance (n) & -0.35 & $-0.56^{*}$ & -0.06 & 0.23 & -0.18 & - & $-0.53^{*}$ & -0.23 \\
\hline Elevation (m) & $0.65^{* *}$ & $0.77^{* *}$ & $0.69^{* *}$ & $-0.53^{*}$ & 0.07 & $-0.53^{*}$ & - & $-0.49^{*}$ \\
\hline Coast (m) & 0.13 & 0.19 & 0.31 & -0.04 & -0.03 & -0.23 & $-0.49^{*}$ & - \\
\hline \multicolumn{9}{|l|}{ NNK } \\
\hline Age (mean, yr) & - & $0.82^{* *}$ & $0.53^{*}$ & -0.43 & -0.01 & $-0.55^{*}$ & $0.74^{* *}$ & 0.24 \\
\hline QMD $(\mathrm{cm})$ & $0.82^{* *}$ & - & $0.53^{*}$ & $-0.61^{* *}$ & 0.17 & $-0.55^{*}$ & $0.80^{* *}$ & -0.11 \\
\hline Basal area $\left(\mathrm{m}^{2} \mathrm{ha}^{-1}\right)$ & $0.53^{*}$ & $0.53^{*}$ & - & -0.47 & -0.07 & -0.06 & $0.59^{* *}$ & -0.31 \\
\hline $\mathrm{DD}(\mathrm{n})$ & -0.43 & $-0.61^{* *}$ & -0.47 & - & -0.49 & 0.21 & $-0.76^{*}$ & -0.12 \\
\hline $\mathrm{DD}(\mathrm{dbh}, \mathrm{cm})$ & -0.01 & 0.17 & -0.07 & -0.49 & - & -0.24 & 0.29 & 0.26 \\
\hline Abundance (n) & $-0.55^{*}$ & $-0.55^{*}$ & -0.06 & 0.21 & -0.24 & - & $-0.53^{*}$ & -0.23 \\
\hline Elevation (m) & $0.74^{* *}$ & $0.80^{* *}$ & $0.59^{* *}$ & $-0.76^{*}$ & 0.29 & $-0.53^{*}$ & - & $-0.49^{*}$ \\
\hline Coast (m) & 0.24 & -0.11 & 0.31 & -0.12 & 0.26 & -0.23 & $-0.49^{*}$ & - \\
\hline
\end{tabular}

structure was significantly different between the low and high elevation groups. On NNK, vegetation structure was found to be significantly different between all elevation groups (Table 4).

\section{Maximum tree age}

In general, Pinus elliottii var. densa individuals were younger at NNK than at BPK, with the oldest individual at NNK dating back to $1870(\mathrm{n}=2)$ compared to 1757 at BPK $(n=1)$ (Table 5). The oldest living tree found across both sites (sample BPK048) established in the year $1757 \mathrm{CE}$ ( $257 \mathrm{yr}$ old) and was rooted at $1.51 \mathrm{~m}$ above sea level. As with the plot data, the relationship between age and elevation was strongly positive with targeted old $P$. elliottii var. densa individuals (BPK: $r=0.78$; NNK: $r=71$; $\mathrm{p}<0.01$.

\section{Remote sensing}

Along with being the larger island, the distribution of elevation variance on BPK demonstrated higher leptokurtism, with more land area distributed at higher elevations compared to NNK (Fig. 2). Both islands, however, displayed a similar spatial profile, with island interiors characterized by the higher elevation. A general pattern of lower elevations experiencing more NDVI change and higher locales expe- riencing less was demonstrated at the island scale on both BPK and NNK during the period 2001 to 2011 (Fig. 6). One-way ANOVA tests indicated that mean NDVI change between elevation groups was significantly different (Tukey's test $\mathrm{p}<0.05$; Table 6 ) on both islands and between all elevation groups (i.e. low, middle, high) for the time period and study area considered.

\section{DISCUSSION}

\section{Long-term survival of a foundation species}

Our analyses of primary data (ground-based vegetation) and secondary data (RS) support the hypothesis that fine-scale elevation gradient has an influence not only on the long-term survival of $P$. elliottii var. densa with regard to repeated wind- and storm surge-derived disturbance over multiple centuries but also on the development of complex, old-growth pine savanna as well. An important consideration in the interpretation of the results is the realization that our primary and secondary data represent different spatial and temporal scales. Plot-level data were gathered from study sites on BPK and NNK (e.g. Fig. 2), while RS data were analyzed at the island scale (e.g. Fig. 3). Temporally, while certain forestry metrics are representative of vegetation dynamics at the decadal to centennial scale (i.e. mean plot age, maximum tree age), other parameters represent a 

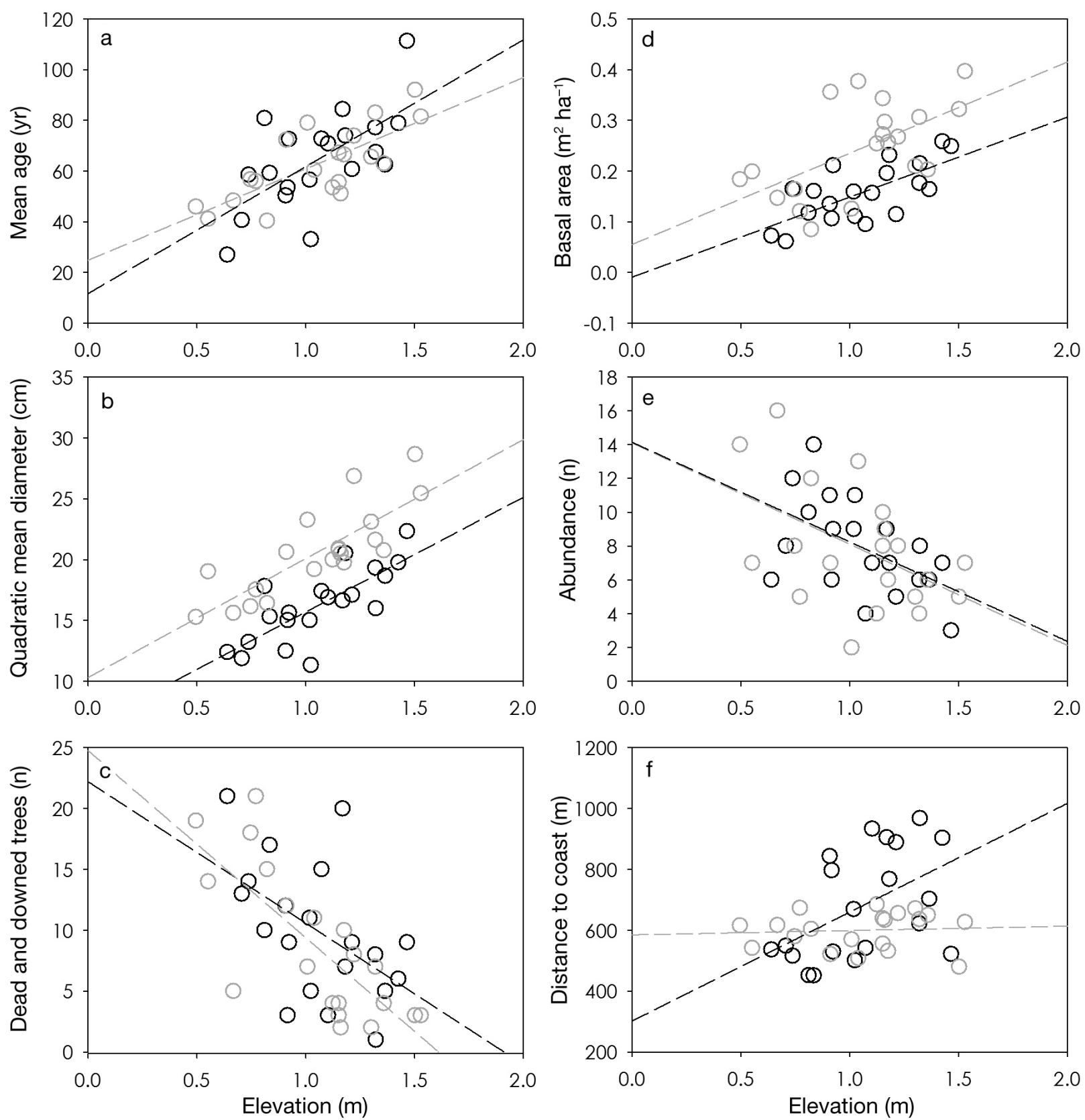

Fig. 4. Linear regression charts for the Big Pine Key (black) and No Name Key (grey) sites, Florida Keys, showing relationships between elevation (m) and (a) mean plot tree age, (b) mean plot quadratic mean diameter (cm), (c) total number of dead and downed material (n), (d) mean plot basal area $\left(\mathrm{m}^{2} \mathrm{ha}^{-1}\right)$, (e) total plot tree abundance (n), and (f) Euclidean distance of each plot to the coastline

snapshot of structural conditions (i.e. QMD, basal area, dead and downed trees, abundance). Despite scalar differences between the primary and secondary sources, both suggest a similar influence of elevation on vegetation, and results are thus interpreted in the same way. Thus, we use the RS analyses as supporting evidence that strengthens the vegetationelevation results gleaned from plot-level data.
The mechanisms responsible for permitting the long-term survival of $P$. elliottii var. densa in a highdisturbance environment are likely a combination of adaptive tree architecture (e.g. Everham \& Brokaw 1996, Platt et al. 2000) and associated protection from storm surge for trees rooted at higher elevations. Although not measured, visual comparisons between P. elliottii var. densa trees on mainland Florida and 
Table 3. Parameters of principal component analysis (PCA) and Pearson correlations between PC axes and dependent variables. DD: dead and downed trees; QMD: quadratic mean diameter; BA: basal area; BPK: Big Pine Key; NNK: No Name Key; -: no data. ${ }^{* *} \mathrm{p}<0.01$

\begin{tabular}{|c|c|c|c|c|c|c|c|}
\hline & \multicolumn{2}{|c|}{ PCA parameter } & \multirow[b]{2}{*}{$\begin{array}{l}\text { Age } \\
\text { (yr) }\end{array}$} & \multicolumn{4}{|c|}{ - Correlation with variables } \\
\hline & $\begin{array}{l}\text { Eigen- } \\
\text { value }\end{array}$ & $\begin{array}{c}\text { Variance } \\
(\%)\end{array}$ & & $\begin{array}{l}\mathrm{DD} \\
(\mathrm{n})\end{array}$ & $\begin{array}{l}\text { QMD } \\
(\mathrm{cm})\end{array}$ & $\begin{array}{c}\text { BA } \\
\left(\mathrm{m}^{2} \mathrm{ha}^{-1}\right)\end{array}$ & $\begin{array}{l}\text { Abundance } \\
\text { (n) }\end{array}$ \\
\hline \multicolumn{8}{|l|}{ BPK } \\
\hline $\mathrm{PC}_{1}$ & 2.81 & 56 & $0.90^{* *}$ & $-0.43^{* *}$ & $0.95^{* *}$ & * $0.78^{* *}$ & $-0.54^{* *}$ \\
\hline $\mathrm{PC}_{2}$ & 0.99 & 20 & 0.21 & 0.27 & -0.05 & $0.51^{* *}$ & $0.78^{* *}$ \\
\hline $\mathrm{PC}_{3}$ & 0.9 & 18 & - & - & - & - & - \\
\hline \multicolumn{8}{|l|}{ NNK } \\
\hline $\mathrm{PC}_{1}$ & 2.98 & 60 & $0.89^{* *}$ & $-0.70^{* *}$ & $0.93^{* *}$ & * $0.67^{* *}$ & $-0.60^{* *}$ \\
\hline $\mathrm{PC}_{2}$ & 0.96 & 20 & -0.15 & -0.36 & -0.07 & $0.57^{* *}$ & $0.73^{* *}$ \\
\hline $\mathrm{PC}_{3}$ & 0.57 & 11 & - & - & - & - & - \\
\hline
\end{tabular}
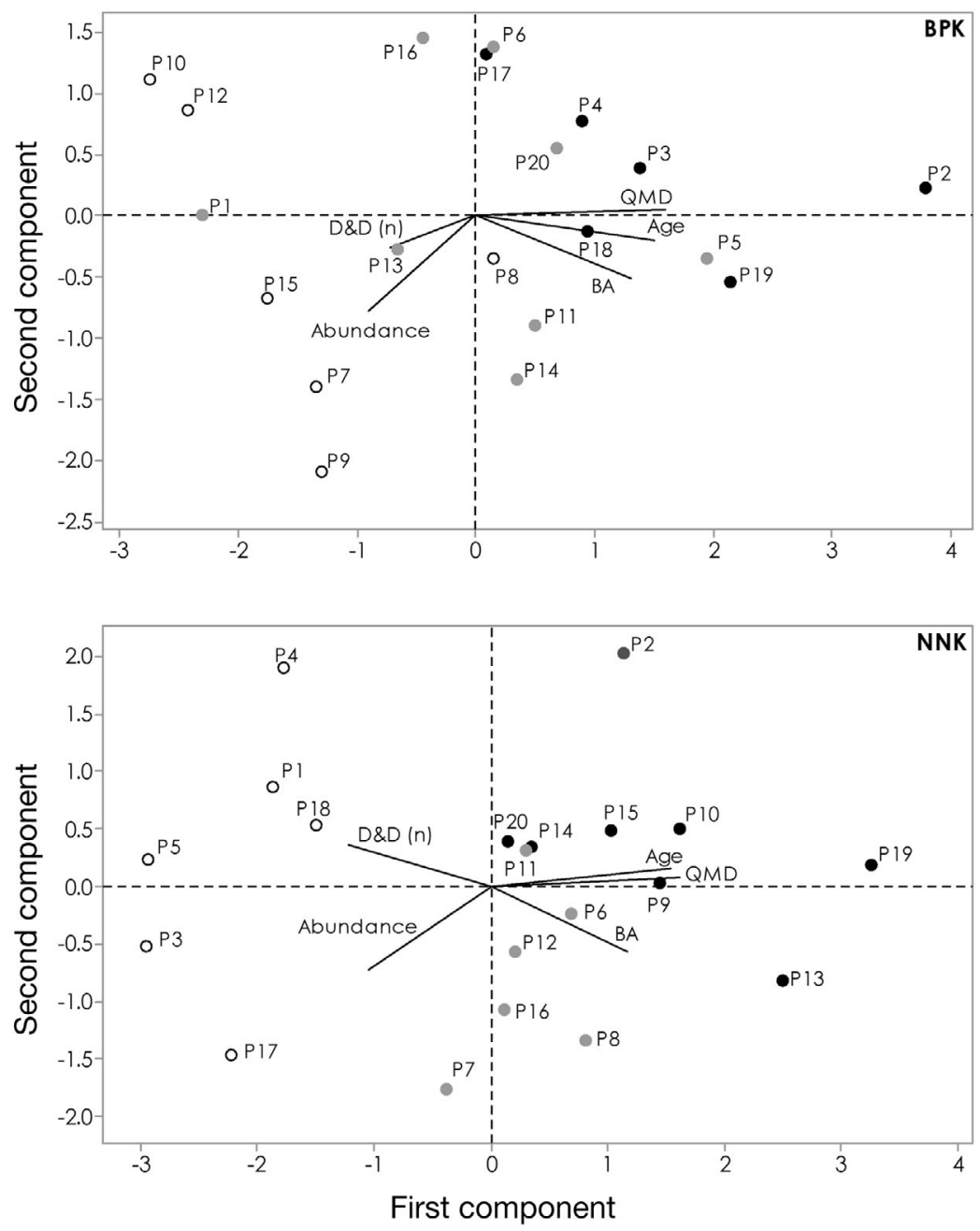

Fig. 5. Principal component analysis biplots for Big Pine Key (BPK, top) and No Name Key (NNK, bottom), in which vectors represent vegetation parameters and circles represent vegetation plots (i.e. P1 is plot \#1), with associated groups in low (open), middle (gray), and high (black) elevation classes. BA: basal area; $\mathrm{D} \& \mathrm{D}=$ dead and downed trees; QMD: quadratic mean diameter the Florida Keys indicate a marked difference in stature of individuals on the Florida mainland. The architecture of $P$. elliottii var. densa in the Florida Keys contains features that likely contribute to survival against wind disturbance, such as shorter stems with flatter and broader crowns. Because soils are thin to nonexistent, root systems are laterally spreading and anchored in the surficial Miami limestone, which might also provide additional resistance against strong winds. Canopy architecture, however, does not protect against storm surge. Elevation is thus important for creating mosaics of varied vegetation structure over the land surface related to storm surge events over the past several hundred years.

Hurricane Wilma is the most recent TC to produce a major impact on BPK and NNK. The storm created 2 separate surges on 23-24 October 2005, with a maximum surge of $2 \mathrm{~m}$ (FEMA 2006). Of all plots $(\mathrm{n}=40)$, trees $(\mathrm{n}=$ 335), and associated elevations included in this study, the oldest tree (257 yr) was found at the highest elevation at just over $1.5 \mathrm{~m}$, which suggests that this tree and both BPK and NNK sites were inundated with saltwater during the Hurricane Wilma surge. Following the storm, the survival of plants was controlled by elevation and drainage patterns (Sah et al. 2010) in that storm surge, and associated salt deposits remained on the surface and failed to move through the system due to historic drought (Ross et al. 2009). On BPK, survival of $P$. elliottii var. densa rooted above $1 \mathrm{~m}$ was $\geq 75 \%$, whereas $<20 \%$ survived at lower elevations (Sah et al. 2010), which strongly supports our findings. A similar mortality-driven TC-drought interaction was also found in coastal northern Florida (DeSantis et al. 2007). Although storm surge from Hurricane Wilma and numerous storms over the past ca. 250 yr have inundated BPK and NNK, the long-term persistence 
Table 4. Results from 1-way ANOVA tests and Tukey-Kramer post hoc means comparison for plot-level vegetation structure data within elevation groups. BPK: Big Pine Key; NNK: No Name Key; DD: dead and downed trees; QMD: quadratic mean diameter; BA: basal area. Asterisks indicate significant differences within a row: ${ }^{*} \mathrm{p}<0.05 ;{ }^{* *} \mathrm{p}<0.10$

\begin{tabular}{|lccc|}
\hline \multirow{2}{*}{ Parameter } & \multicolumn{3}{c|}{ Elevation group } \\
\cline { 2 - 4 } & Low & Middle & High \\
\hline BPK & & & \\
Plots/group (n) & 6 & 8 & 6 \\
Elevation range (m) & $0.55-0.78$ & $0.79-1.01$ & $1.02-1.26$ \\
Age & $53^{* *}$ & 65 & $77^{* *}$ \\
DD (n) & $15^{*}$ & 9 & $6^{*}$ \\
QMD & $13^{*}$ & 16 & $19^{*}$ \\
BA & $0.12^{*}$ & 0.15 & $0.19^{*}$ \\
Abundance & $10^{*}$ & 8 & $6^{*}$ \\
NNK & & & \\
Plots/group (n) & 6 & 7 & 7 \\
Elevation range (m) & $0.43-0.78$ & $0.79-1.01$ & $1.02^{*}-1.31$ \\
Age & $48^{*}$ & $63^{*}$ & $75^{*}$ \\
DD (n) & $15^{*}$ & $6^{*}$ & $5^{*}$ \\
QMD & $16^{*}$ & $21^{*}$ & $24^{*}$ \\
BA & $15^{*}$ & $27^{*}$ & $28^{*}$ \\
Abundance & $10^{* *}$ & 8 & $6^{* *}$ \\
\hline
\end{tabular}

Table 5. Associated tree age and elevation for targeted living old-growth Pinus elliottii var. densa individuals containing pith collected at Big Pine Key (PBK) and No Name Key (NNK), Florida Keys, USA. Tree ages are calculated from establishment year to 2014. Relationship between age and elevation: BPK r $=0.79, \mathrm{p}<0.01, \mathrm{n}=14$; NNK $\mathrm{r}=0.72, \mathrm{p}<$ $0.01, \mathrm{n}=7$

\begin{tabular}{|lcrc|}
\hline Sample & $\begin{array}{c}\text { Establishment } \\
\text { year }\end{array}$ & $\begin{array}{c}\text { Age } \\
(\mathrm{yr})\end{array}$ & $\begin{array}{c}\text { Elevation } \\
(\mathrm{m})\end{array}$ \\
\hline BPK502 & 1898 & 116 & 0.79 \\
BPK503 & 1929 & 85 & 0.85 \\
BPK017 & 1880 & 134 & 0.93 \\
BPK510 & 1902 & 112 & 0.98 \\
BPK515 & 1885 & 129 & 0.99 \\
BPK513 & 1911 & 103 & 1.09 \\
BPK036 & 1873 & 141 & 1.13 \\
BPK019 & 1932 & 82 & 1.17 \\
BPK015 & 1867 & 147 & 1.21 \\
BPK041 & 1785 & 229 & 1.24 \\
BPK050 & 1815 & 199 & 1.25 \\
BPK047 & 1789 & 225 & 1.3 \\
BPK042 & 1810 & 204 & 1.46 \\
BPK048 & 1757 & 257 & 1.51 \\
NNK050 & 1911 & 103 & 0.91 \\
NNK080 & 1921 & 93 & 0.94 \\
NNK012 & 1919 & 95 & 0.96 \\
NNK002 & 1895 & 119 & 0.98 \\
NNK021 & 1913 & 101 & 1.1 \\
NNK014 & 1870 & 144 & 1.09 \\
NNK084 & 1870 & 144 & 1.17 \\
\hline
\end{tabular}

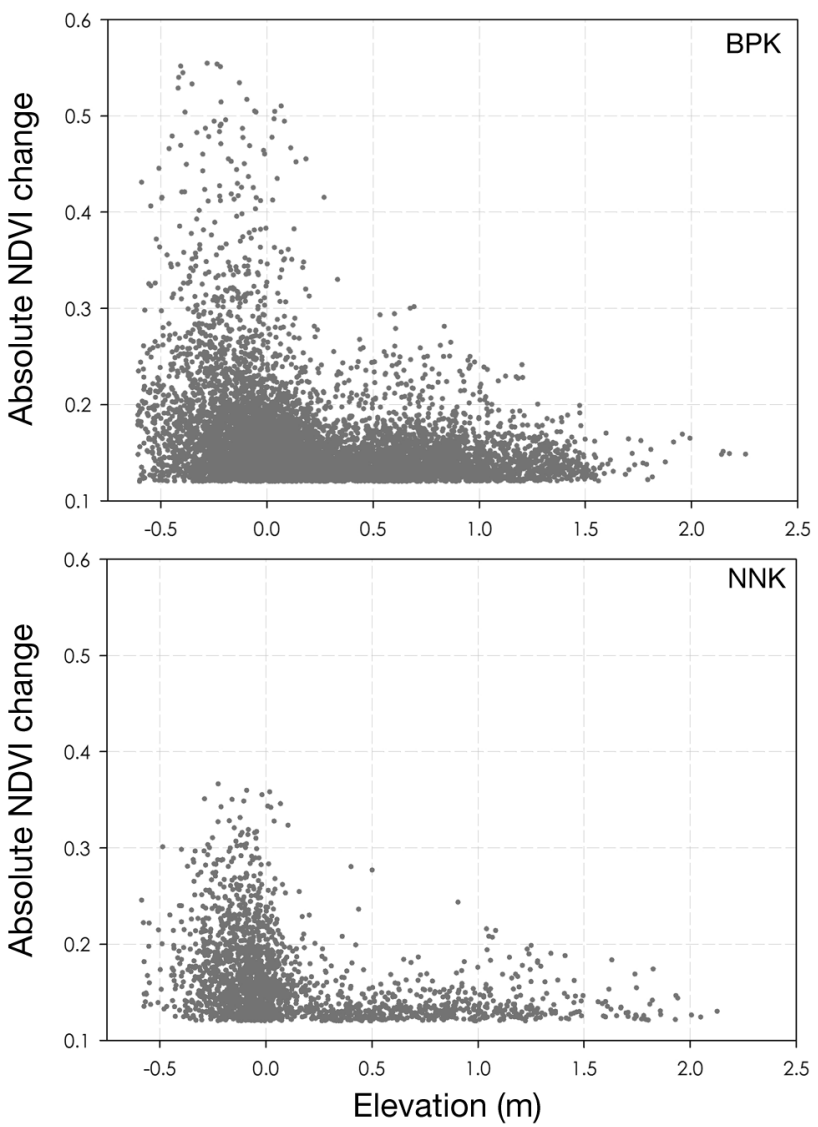

Fig. 6. Scatter plot showing relationship between absolute normalized difference vegetation index (NDVI) change and elevation (m) for all pixels analyzed for Big Pine Key (BPK, top, $\mathrm{n}=7759$ ) and No Name Key (NNK, bottom, $\mathrm{n}=2005$ )

Table 6. Results from 1-way ANOVA tests and TukeyKramer post hoc means comparison for normalized difference vegetation index (NDVI) change detection within elevation groups at Big Pine Key (BPK) and No Name Key

(NNK), Florida Keys, USA. ${ }^{*} \mathrm{p}<0.05$ (Tukey's test)

\begin{tabular}{|lccc|}
\hline \multirow{2}{*}{ Parameter } & \multicolumn{3}{c|}{$\begin{array}{c}\text { Elevation group } \\
\text { Middle }\end{array}$} \\
\cline { 2 - 3 } & Low & High \\
\hline BPK & & & \\
Pixels (n) & 2586 & 2632 & 2541 \\
Elevation range & -0.600 to & -0.031 to & 0.390 to \\
$(m)$ & -0.030 & 0.380 & 2.260 \\
NDVI change & $0.19^{*}$ & $0.16^{*}$ & $0.14^{*}$ \\
NNK & & & \\
Pixels (n) & 656 & 637 & 712 \\
Elevation range & -0.586 to & -0.091 to & 0.101 to \\
(m) & -0.090 & 0.100 & 2.13 \\
NDVI change & $0.18^{*}$ & $0.17^{*}$ & $0.14^{*}$ \\
\hline
\end{tabular}


of $P$. elliottii var. densa individuals and development of old-growth pine rocklands is possible at higher elevations.

\section{Vegetation structure and elevation}

Vegetation structure across the 40 plots at both the BPK and NNK sites revealed a common pattern of structure relative to elevation that exists in pine rockland communities, and this pattern was further bolstered with finding less NDVI change at higher elevations during the period 2001 to 2011. An important consideration in the interpretation of vegetation structure results is that elevation is one of several drivers of vegetation patterns within Florida Keys pine rocklands. Irrespective of natural and anthropogenic disturbance, complex interactions and indirect effects among elevation (Ross et al. 1992, 1994, 2009, Maschinski et al. 2011, S. Saha et al. 2011), fire (Sah et al. 2010), and groundwater salinity (Ross et al. 1992) drive vegetation patterns in rockland communities. Thus, elevation alone is not the sole influence on vegetation structure. We are not the first to acknowledge the influence of elevation on pine rockland vegetation patterns. Ross et al. (1992) noted the connection between elevation gradient within individual islands, with the majority of pines located on upland site locations. Maschinski et al. (2011) further expanded this notion and highlighted conservation strategies for rare and endemic species within pine rocklands, as well as the entire community, with regard to elevation and sea level rise. Here, we build on these and other previous studies and provide the ability to identify core conservation areas using spatial vegetation structure and tree age data, particularly if conservation decisions are made to conduct in situ improvement of ecosystem resiliency (Maschinski et al. 2011).

The maximum $P$. elliottii var. densa age data provided a new perspective of the long-term age potential for the species (Brown 1996) as well as an ageelevation relationship that mirrored the plot-level vegetation data. The BPK plot containing the oldest mean age (111.3 yr) was located at the highest elevation of all plots $(1.47 \mathrm{~m})$ included in the study, and this was the general pattern at NNK as well. Likewise, the oldest targeted tree we found on both islands was rooted within the BPK site at an elevation of $1.51 \mathrm{~m}$. The spatial representation of the plot scores on $\mathrm{PC}_{1}-$ which explained a large amount of variance at both sites and produced the only eigenvalue greater than 1 -indicates the influence that fine-scale elevation variation has on pine rockland savanna structure. All elevation groups at NNK were significantly different $(p<0.05)$ in tree age, size, basal area, abundance, and the amount of remnant material. At BPK, however, only the lowest and highest elevation groups were significantly different. This finding could be an artifact of the wider range of elevation between plots installed at NNK compared to BPK. At NNK, elevation range between plots was $0.88 \mathrm{~m}(0.43$ to $1.31 \mathrm{~m})$, whereas the range at BPK was $0.71 \mathrm{~m}$ (0.55 to $1.26 \mathrm{~m}$ ). Compared to lower habitat areas, higher elevations had marked structural differences and are comprised of larger, older, and fewer trees. Yet, despite the intraspecific elevation range between sites, such small differences in topographic relief demonstrate the subtle but strong influence that fine-scale elevation change has on driving vegetation patterns across islands in the Florida Keys, particularly in a region with a highly frequent natural disturbance regime dominated by TCs.

The influence of TC-derived wind damage on vegetation patterns is well documented (e.g. Foster \& Boose 1992, Boose et al. 1994, Foster \& Motzkin 1998, Platt et al. 2000, Bellingham et al. 2005, Tsujino et al. 2006). In pine savannas of the southern Florida mainland, Platt et al. (2000) reported P. elliottii var. densa to be resistant to the damaging winds during Hurricane Andrew (1992), and mortality was lower in oldgrowth stands $(16.9 \% \pm 3.1$, mean $\pm \mathrm{SE})$ compared to second-growth stands. However, the importance of fine-scale elevation gradient on vegetation patterns with regard to TC-induced storm surge is less documented.

The demonstrated resistance of $P$. elliottii var. densa to wind damage (e.g. Platt et al. 2000) and the linkage between old-growth vegetation structure and fine-scale elevation variation indicates that TCinduced storm surge, rather than wind, is the primary disturbance agent in pine savannas of the Florida Keys (e.g. Craighead \& Gilbert 1962, Gardner et al. 1992, Ross et al. 2009). Thus, similarities exist between the role that elevation plays in the Florida Keys pine savannas and riparian zone bottomland forests. The role of microtopography in ecosystem development and function in bottomland regions has been widely demonstrated. Microtopographic variation, for example in the form of ridges, sloughs, flats, and hummocks, control local hydrologic conditions and soils, which influences the establishment and survival of plant species (Hodges 1997, Grell et al. 2005, Simmons et al. 2012).

As an underlying mechanism for controlling vegetation structure in the Florida Keys, the importance of 
fine-scale elevation variance was also demonstrated in an old-growth bottomland hardwood-P. taeda forest in Arkansas. Grell et al. (2005) analyzed a wide range of forest metrics and environmental physiognomies grouped in $0.50 \mathrm{~m}$ elevation classes along a $1.5 \mathrm{~m}$ gradient and concluded that vegetation structure was primarily controlled by subtle elevation variations. At $\mathrm{BPK}$, high, middle, and low elevation classes covered group ranges of $0.22,0.23$, and $0.24 \mathrm{~m}$ over an elevation gradient of $0.71 \mathrm{~m}$, and groups at NNK covered ranges of $0.35,0.22$, and $0.29 \mathrm{~m}$ over a $0.88 \mathrm{~m}$ gradient. Compared to the elevation groups and gradient used by Grell et al. (2005), vegetation structure of pine rocklands in the Florida Keys is controlled by elevation differences that vary at a similar but finer scale.

We demonstrate the importance of elevation gradient on controlling pine rockland vegetation structure within the 2 largest remaining habitat areas in the Florida Keys, BPK and NNK. Combined disturbances of habitat fragmentation, fire (Bergh \& Wisby 1996, Sah et al. 2010, Harley et al. 2013), sea level rise (Ross et al. 1994, 2009, A. K. Saha et al. 2011), and TCs (Platt et al. 2002, Ross et al. 2009, Sah et al. 2010, S. Saha et al. 2011) have limited the geographic distribution of the endangered pine rockland ecosystem in the Florida Keys. Despite existing in such a highfrequency disturbance regime with multiple agents, the long-term persistence of the foundation species $P$. elliottii var. densa depends on elevation variations that exist at a sub-meter scale. We provide better understanding of pine rockland demography with respect to elevation controls that can be used to aid in situ conservation efforts in the Florida Keys. Despite our limited geographic scope, the influence of North Atlantic TCs on ecosystems along the Gulf and Atlantic coasts is severe and widespread. Thus, the strong elevation-vegetation structure relationships shown on these 2 islands might operate along similar gradients and scales in other related environments, such as other low-relief carbonate islands in the Caribbean region or transgressive barrier island systems along the Gulf and Atlantic coasts of the USA.

Acknowledgements. Support was provided by the National Science Foundation under Grant Nos. 1002479 and 0538420 and by the US Fish and Wildlife Service. We thank Anne Morkill and Chad Anderson for access to the National Key Deer Refuge, and Henri Grissino-Mayer, Sally Horn, John Sakulich, Rebecca Stratton, Kody Honeyman, Niki Garland, Ann McGhee, and Alex Pilote for field assistance. We thank 2 anonymous reviewers for giving their time and energy to offer comments and suggestions that improved earlier drafts of this manuscript.

\section{LITERATURE CITED}

Applequist MB (1958) A simple pith locator for use with offcentre increment cores. J For 56:141

Åström M, Dynesius M, Hylander K, Nilsson C (2007) Slope aspect modifies community responses to clear-cutting in boreal forests. Ecology 88:749-758

Batista WB, Platt WJ (2003) Tree population responses to hurricane disturbance: syndromes in a south-eastern USA old-growth forest. J Ecol 91:197-212

Bellingham PJ, Tanner EV, Healey JR (2005) Hurricane disturbance accelerates invasion by the alien tree Pittosporum undulatum in Jamaican montane rain forests. J Veg Sci 16:675-684

Bergh C, Wisby J (1996) Fire history of lower Keys pine rocklands. Nature Conservancy, Florida Keys Initiative, Key West, FL

Boose ER, Foster DR, Fluet M (1994) Hurricane impacts to tropical and temperate forest landscapes. Ecol Monogr 64:369-400

Brown PM (1996) OLDLIST: a database of maximum tree ages. In: Dean JS, Meko DM, Swetnam TW (eds) Tree rings, environment and humanity: Proceedings of the International Conference, Tucson, Arizona, 17-21 May, 1994. Radiocarbon Tuscon, AZ, p 727-731

Craighead FC, Gilbert VC (1962) The effects of Hurricane Donna on the vegetation of southern Florida. Q J Fla Acad Sci 25:1-28

Curtis RO, Marshall DD (2000) Why quadratic mean diameter? West J Appl For 15:137-139

Danz NP, Reich PB, Frelich LE, Niemi GJ (2011) Vegetation controls vary across space and spatial scale in a historic grassland-forest biome boundary. Ecography 34: 402-414

DeSantis LR, Bhotika S, Williams K, Putz FE (2007) Sea level rise and drought interactions accelerate forest decline on the Gulf Coast of Florida USA. Glob Change Biol 13: 2349-2360

Everham EM III, Brokaw NVL (1996) Forest damage and recovery from catastrophic wind. Bot Rev 62:113-185

FEMA (Federal Emergency Management Agency) (2006) Final coastal high water mark collection for Hurricane Wilma in Florida. Hazard Mitigation Technical Assistance Program, FEMA-1609-DR-FL, Task Order 460. URS Group, Gaithersburg, MD

Foster DR (1988) Species and stand response to catastrophic wind in central New England, USA. J Ecol 76:135-151

Foster DR, Boose ER (1992) Patterns of forest damage resulting from catastrophic wind in central New England, USA. J Ecol 80:79-98

Foster DR, Motzkin G (1998) Ecology and conservation in the cultural landscape of New England: lessons from nature's history. Northeast Nat 5:111-126

Gardner LR, Michener WK, Williams TM, Blood ER and others (1992) Disturbance effects of Hurricane Hugo on a pristine coastal landscape: North Inlet, South Carolina, USA. Neth J Sea Res 30:249-263

Grell AG, Shelton MG, Heitzman E (2005) Changes in plant species composition along an elevation gradient in an old-growth bottomland hardwood-Pinus taeda forest in southern Arkansas. J Torrey Bot Soc 132:72-89

Harley GL, Grissino-Mayer HD, Horn SP (2013) Fire history and forest structure of an endangered subtropical ecosystem in the Florida Keys USA. Int J Wildland Fire 22: 394-404 
Hodges JD (1997) Development and ecology of bottomland hardwood sites. For Ecol Manage 90:117-125

Hopkinson CS, Lugo AE, Alber M, Covich AP, Van Bloem SJ (2008) Forecasting effects of sea-level rise and windstorms on coastal and inland ecosystems. Front Ecol Environ 6:255-263

Hylander K (2005) Aspect modifies the magnitude of edge effects on bryophyte growth in boreal forests. J Appl Ecol 42:518-525

Kiss L, Magnin F (2003) The impact of fire on some Mediterranean land snail communities and patterns of post-fire recolonization. J Molluscan Stud 69:43-53

Lugo AE (2008) Visible and invisible effects of hurricanes on forest ecosystems: an international review. Austral Ecol 33:368-398

Maschinski J, Ross MS, Liu H, O'Brien J, von Wettberg EJ, Haskins KE (2011) Sinking ships: conservation options for endemic taxa threatened by sea level rise. Clim Change 107:147-167

Matthaei CD, Arbuckle CJ, Townsend CR (2000) Stable surface stones as refugia for invertebrates during disturbance in a New Zealand stream. J N Am Benthol Soc 19: 82-93

Needham HF, Keim BD (2012) A storm surge database for the US Gulf Coast. Int J Climatol 32:2108-2123

Palik BJ, Pederson N (1996) Overstory mortality and canopy disturbances in longleaf pine ecosystems. Can J Res 26: 2035-2047

Pederson N (2010) External characteristics of old trees in the eastern deciduous forest. Nat Areas J 30:396-407

Pimm SL, Davis GE, Loope L, Roman CT, Smith TJ III, Tilmant JT (1994) Hurricane Andrew. BioScience 44:224-229

Platt WJ, Rathbun SL (1993) Dynamics of an old-growth longleaf pine population. Proc Tall Timbers Fire Ecol Conf 18:275-297

Platt WJ, Evans GW, Davis MM (1988) Effects of fire season on flowering of forbs and shrubs in longleaf pine forests. Oecologia 76:353-363

Platt WJ, Doren RF, Armentano TV (2000) Effects of Hurricane Andrew on stands of slash pine Pinus elliottii var. densa in the everglades region of south Florida (USA). Plant Ecol 146:43-60

Platt WJ, Beckage B, Doren RF, Slater HH (2002) Interactions of large-scale disturbances: prior fire regimes and hurricane mortality of savanna pines. Ecology 83: 1566-1572

Editorial responsibility: Hans Juergen Boehmer, Bonn, Germany
Ross MS, O'Brien JJ, Flynn LJ (1992) Ecological site classification of Florida Keys terrestrial habitats. Biotropica 24: 488-502

Ross MS, Obrien JJ, Sternberg LDL (1994) Sea-level rise and the reduction in pine forests in the Florida Keys. Ecol Appl 4:144-156

Ross MS, O'Brien JJ, Ford RG, Zhang K, Morkill A (2009) Disturbance and the rising tide: the challenge of biodiversity management on low-island ecosystems. Front Ecol Environ 7:471-478

Sah JP, Ross MS, Koptur S, Snyder JR (2004) Estimating aboveground biomass of broadleaved woody plants in the understory of Florida Keys pine forests. For Ecol Manage 203:319-329

Sah JP, Ross MS, Snyder JR, Ogurcak DE (2010) Tree mortality following prescribed fire and a storm surge event in slash pine Pinus elliottii var. densa forests in the Florida Keys, USA. Int J For Res 2010:204795

Saha AK, Saha S, Sadle J, Jiang J and others (2011) Sea level rise and South Florida coastal forests. Clim Change 107: 81-108

Saha S, Bradley K, Ross MS, Hughes P, Wilmers T, Ruiz PL, Bergh C (2011) Hurricane effects on subtropical pine rocklands of the Florida Keys. Clim Change 107:169-184

Schmalholz M, Hylander K (2011) Microtopography creates small scale refugia for boreal forest floor bryophytes during clear-cut logging. Ecography 34:637-648

Simmons ME, Wu XB, Whisenant SG (2012) Responses of pioneer and later successional plant assemblages to created microtopographic variation and soil treatments in riparian forest restoration. Restor Ecol 20:369-377

Snyder JR, Herndon A, Robertson WB (1990) South Florida rockland. In: Myers RL, Ewel JJ (eds) Ecosystems of Florida. University Press of Florida, Gainesville, FL, p 230-277

Stokes MA, Smiley TL (1968) An introduction to tree-ring dating. University of Arizona Press, Tucson, AZ

Tsujino R, Takafumi H, Agetsuma N, Yumoto T (2006) Variation in tree growth, mortality and recruitment among topographic positions in a warm temperate forest. J Veg Sci 17(3):281-290

USFWS (US Fish and Wildlife Service) (2009) U.S. fish and wildlife service species assessment and listing priority assignment form date of annual review:May 16, 2009 conducted by: Paula Halupa. South Florida Ecological Services Office, FL

Submitted: May 13, 2015; Accepted: October 9, 2015

Proofs received from author(s): December 2, 2015 